\title{
THE ALGORITHM OF GIVING AUTOMATIC HARAKAT ON ARABIC SCRIPT
}

\author{
${ }^{a}$ Dini Hidayatul Qudsi, ${ }^{b}$ Maksum Ro'is Adin Saf \\ ${ }^{a}$ Information System Department, Politeknik Caltex Riau, Pekanbaru-Indonesia \\ ${ }^{\mathrm{b}}$ Informatics Engineering Department, Politeknik Caltex Riau, Pekanbaru-Indonesia \\ E-mail: dinihq@pcr.ac.id
}

\begin{abstract}
The majority of Arabic reference books in Arabic writing without a vowel/harakat cause students to have difficulty in learning Arabic. Reading Arabic Script without harakat requires an understanding of the science of Nahwu-Sharf (Arabic Grammar) to be able to understand its contents. Therefore, in this study the basic rules of Nahwu-Sharf Science have been translated into an algorithm that can be used to provide an automatic harakat on Arabic script (without harakat). Based on the interview results with the expert, six examples of sentences that represented the types(conditions) of basic sentences in the Arabic language have been used as scenarios to examine the generated algorithm. The allowed sentence is limited to one sentence only and cannot be in the form of poetry or satire. Additionally, Cyclomatic Complexity Testing is used to examine scenarios in a test case. All the steps of the Cyclomatic Complexity have been performed, which are creating the flowgraph, calculating the independent path, and testing scenario. The scenarios were examined in a test case through 13-path test case examination and result match with expected output. In addition, 24 examples which represented the six conditions have been utilized to examine for more detailed analysis and also results accuracy $100 \%$ in accordance with the basic rules of Nahwu-Sharf science.
\end{abstract}

Keywords: Algorithm, Arabic Grammar (Nahwu Sharf Science), Cyclomatic Complexity Testing, Harakat 


\section{INTRODUCTION}

Learning Foreign languages provide many opportunities and benefits not just for personal needs but also in businesses, academics and communications. Arabic is one foreign language that is not less important to master, especially for Muslims around the world. Sirajudeen\&Adebisi [1] suggested that Arabic is a Mother Language of over 300 million people and is used as a National Language in 20 countries. In Indonesia alone, some Indonesian words are adopted from Arabic. Chik [2] stated that there are 3303 Arabic words adopted into Malay.

Given the majority of Indonesian people are Muslims, learning Arabic can facilitate and improve their understanding of Islamic knowledge because Arabic is the language of the holy book of Al Quran and Hadith Scripture which are references for every Muslim in worship and daily life. Oxford [3] suggested that appropriate styles and strategies in learning language can be regarded as major factors in determining student's success in learning a foreign language.

However, in its implementation, Arabic writing which is not supplemented with a vowel/harakat making it difficult for students who want to master Arabic language in which they are accustomed to reading Arabic with harakat and only able to guess how to read Arabic writing without a vowel. This statement is supported by Greene [4] who stated that one of the challenges in learning Arabic is reading a text without vowels.

Al-Jurjani in Abdurrahman [5] also stated that Nahwu is the science that can specify how to arrange the structure of words correctly. In Arabic Grammar (Nahwu-Sharf Science), sentence is called Jumlah, which means a collection of several words. Sentences in Arabic are divided into two types, namely: Jumlah Ismiyah (noun) and Jumlah Fi'liyah (verb) [6]. There are certain conditions in a particular case that depends on the position and the function of the word in the sentence, which are: Rafi', Nasb, Jarr and Jazm [7]. If the word is singular, then to be able to see which case it belongs will depend on what harakah is at the end of the word [8].

In addition, nowadays computer technology can be found anywhere and has became a part of every day's life. Web-based learning media that utilize technology can be a solution for students

to learn reading Arabic writing without harakat. A correct translation of Nahwu-Sharf science into programming algorithms can be used in developing an automated harakat system of Arabic Writing.

An algorithm is a procedure that underlies each command in a computer program that can solve problems involving data processing, computations, or both [9]. There are several ways to specify the algorithm, which are by using the natural language, pseudo code or flowchart. Natural language is the simplest technique to identify algorithms, but often programmers find it difficult to translate into programming languages. Therefore, programmers prefer to utilize other techniques that is clearer and more accurate, such as pseudo code, which is a combination of natural language and programming language. Meanwhile, flowchart can also be used to represent the algorithm in a graphical representation [10].

In order to test the algorithm, Pressman [11] defines Cyclomatic Complexity as a software matrix that provides quantitative measurements of the logical complexity of a program. This method determines the number of independent paths and provides a limit on the number of tests to be performed to ensure all statements have been executed at least once. Preferably, the Cyclomatic Complexity value is limited to 10 because the more complex the module, the more likely error will occur, the more difficult it is to understand, tested and modified [12].

From those statements above, the aim of this study is to develop an algorithm that can provide harakat automatically in Arabic script without harakat. Furthermore, Cyclomatic Complexity Testing will be utilized to examine the accuracy of the algorithm.

\section{AUTOMATIC HARAKAT IN ARABIC SCRIPT}

The research method starts from understanding the basic rules of the NahwuSharf Science (Arabic Grammar) of giving automatic harakat in Arabic script without harakat, translating the rules into algorithm and 
finally, testing the algorithm whether it is in accordance with the rules or not (see Figure 1)

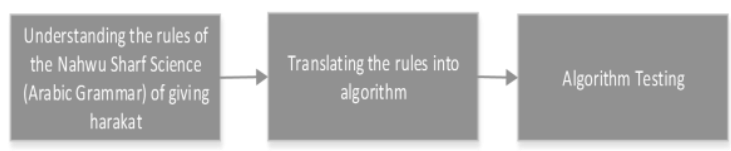

Figure 1. Research Method

\section{Data Collection Procedure}

Some interviews with an Arabic Expert have been conducted to collect the data to understand the basic rules of Nahwu-Sharf Science (Arabic Grammar) of giving automatic harakat. Based on the interview results, the types of basic sentences in the Arabic language can be classified into some conditions as shown in the Table 1.

Table 1. The basic rules of Arabic Grammar

\begin{tabular}{|c|c|c|c|}
\hline No & Condition & $\begin{array}{c}\text { Example } \\
\text { Sentences }\end{array}$ & $\begin{array}{c}\text { Expected } \\
\text { Result }\end{array}$ \\
\hline 1 & $\begin{array}{l}\text { 1. If the first word } \\
\text { is a conjunction } \\
\text { which is not } \downarrow \text { or } \\
\text { L or J or } \vee \\
\text { 2. The second word } \\
\text { should be majrur } \\
\text { 3. Then the third } \\
\text { word should be } \\
\text { marfu' } \\
\text { 4. Then the forth } \\
\text { should be marfu' }\end{array}$ & جيل الفصل تلميذ & 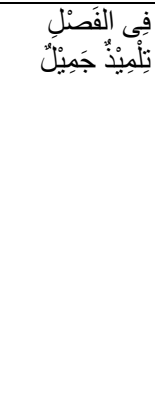 \\
\hline 2 & $\begin{array}{l}\text { 1. if the first word } \\
\text { is a conjunction } \\
\text { which can be } \\
\text { Lل } \\
\text { 2. The second word } \\
\text { should be majzum } \\
\text { 3. Then the third } \\
\text { word should be } \\
\text { marfu' } \\
\text { 4. And the forth } \\
\text { word should be } \\
\text { manshub }\end{array}$ & لَّمَِّّل محمَد & الَُْرََّّأَكُلْ مُحَمَّدُ \\
\hline 3 & $\begin{array}{l}\text { 1. if the first word } \\
\text { is a conjunction } \\
\text { which is } y \\
2 . \text { The second word } \\
\text { should be majzum } \\
\text { 3. Then the third } \\
\text { word is manshub }\end{array}$ & لا تتس المعروف & الَانَتْنَ \\
\hline 4 & $\begin{array}{l}\text { 1. If the first word } \\
\text { is marfu' } \\
\text { 2. The second word } \\
\text { should be marfu' } \\
\text { 3. IF the third word } \\
\text { is not a }\end{array}$ & كتب أحمد & كالدَرَبََ أحمَندُ \\
\hline
\end{tabular}

conjunction, then it

is a manshub

5 1. If the first word

is marfu' and the

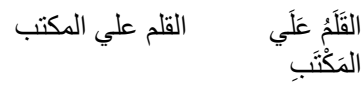

the second word is

a conjunction

2. Then the third

word should be

majrur

$6 \quad$ 1. If the first word

is marfu'

2. Then the second

word should be

marfu'

3. And if the third

word is a

conjunction, then

the forth should be

majrur

\section{Translating the Rules into Algorithm}

There are steps performed to translate the rules into algorithm which are design database and create flowchart of giving automatic harakat.

\section{Database Design}

Two tables were designed in the database to store "dictionary" and "conjunction". 'Dictionary' table stores the words without harakat and the words with their harakat based on I'rab rules, which are: marfu, mansub, majzum and majrur (See Table 2). While, 'Conjunction' table is created to store the conjunction of the sentence. 'Conjuntion' table consists of two fields, which are the conjunction word without harakat (field word) and its word with harakat (field hurf). (See Table 3).

Table 2. Table Structure for Table 'Dictionary'

\begin{tabular}{lll}
\hline Column Name & Type & Null Default \\
\hline idDictionary & Integer & No \\
word & Varchar(25) & No \\
marfu & Varchar(25) & No \\
Manshub & Varchar(25) & No \\
Majzum & Varchar(25) & No \\
Majrur & Varchar(25) & No \\
\hline
\end{tabular}

Table 3: Table Structure for Table 'Conjunction'

\begin{tabular}{lll}
\hline Column Name & Type & Null Default \\
\hline idHurf & Integer & No \\
word & Varchar(25) & No \\
hurf & Varchar(25) & No \\
\hline
\end{tabular}




\section{The Flowchart of Giving Automatic Harakat}

Figure 2 shows the flowchart of giving automatic algorithm on Arabic Script.

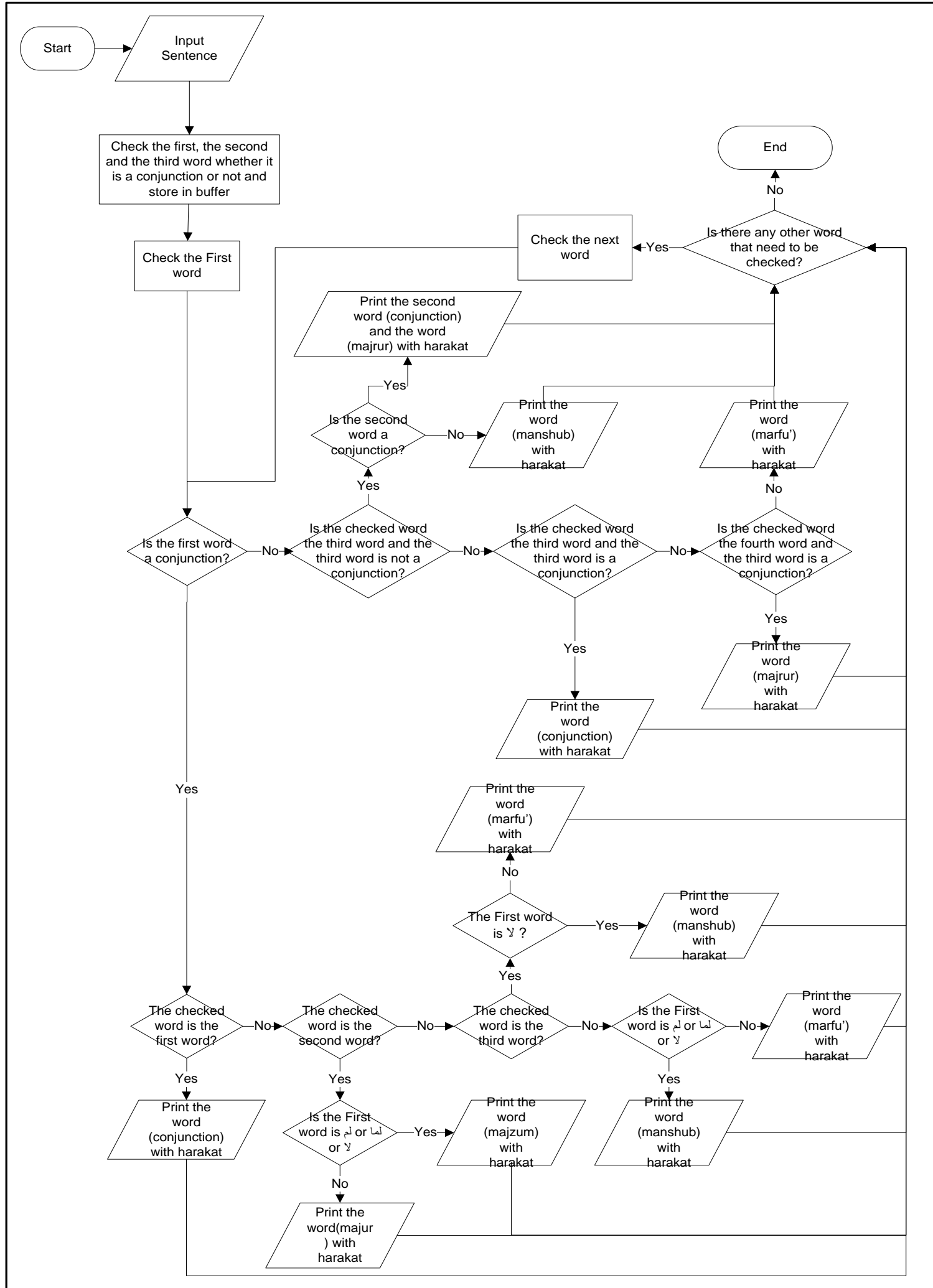

Figure 2. Flowchart of Automatic Giving Harakat on Arabic Script 


\section{The Algorithm of Giving Automatic Harakat}

The finding of this research is the algorithm that was designed based on the conditions explained in Table 1. Figure 3 shows the algorithm to give harakat automatically in Arabic script without harakat.

The explanation of the algorithm from Figure 3 is that:

Number 1 to 2 (refer to the number written on the left in Figure 3): firstly, user will input a sentence into the system. One sentence consists of a maximum 4 words. System will check the first, the second and the third word whether it is a conjunction or not and save them as variables. Then, system will check word by word starting from the first.

Number 3 to 5: System will check the database whether the first word is a conjunction. If yes, system will continue checking whether the word being checked is the first word. If yes, then the system will print the word (conjunction) with harakat.

Number 6 to 9: If the checked word is not the first word, system will check whether the word being checked is the second word. If yes, then system will continue checking whether the first word is for Lor Yor J. If yes, then the system will print the word (majzum) with harakat. If no, then the system will print the word (majrur) with harakat.

Number 10 to 13: If the checked word is not the second word, system will check whether the word being checked is the third word. If yes, then system will continue checking whether the first word is $\gamma$. If yes, then the system will print the word (manshub) with harakat. If no, then the system will print the word (marfu') with harakat

Number 14 to 17: If the checked word is also not the third word, then system will check whether the first word is Jor Lbor vor J. If yes, then the system will print the word (manshub) with harakat. If no, then the system will print the word (marfu') with harakat.

Number 18 to 21: If the first word is not a conjunction, then system will check whether the checked word is the third word and the third word is not a conjunction. Then, system will continue checking whether the second word is a conjunction. If yes, then system will print the word (majrur) with harakat. If no, system will print the word (manshub) with harakat.
Number 22 to 23: If the checked word is the third word and the third word is a conjunction, then system will print the word (conjunction) with harakat.

Number 24 to 25: If the checked word is not the third word and the third word is not a conjunction, then system will check whether the checked word is the forth word and the third word is a conjunction. If yes, system will print the word (majrur) with harakat. If no, then system will print the word (marfu') with harakat.

Number 26 to 28: Other than above conditions mentioned, means that the checked word is marfu', then the system will print the word (marfu') with harakat. Finally, after finish checking all the words one by one, the system will display the sentence with harakat.

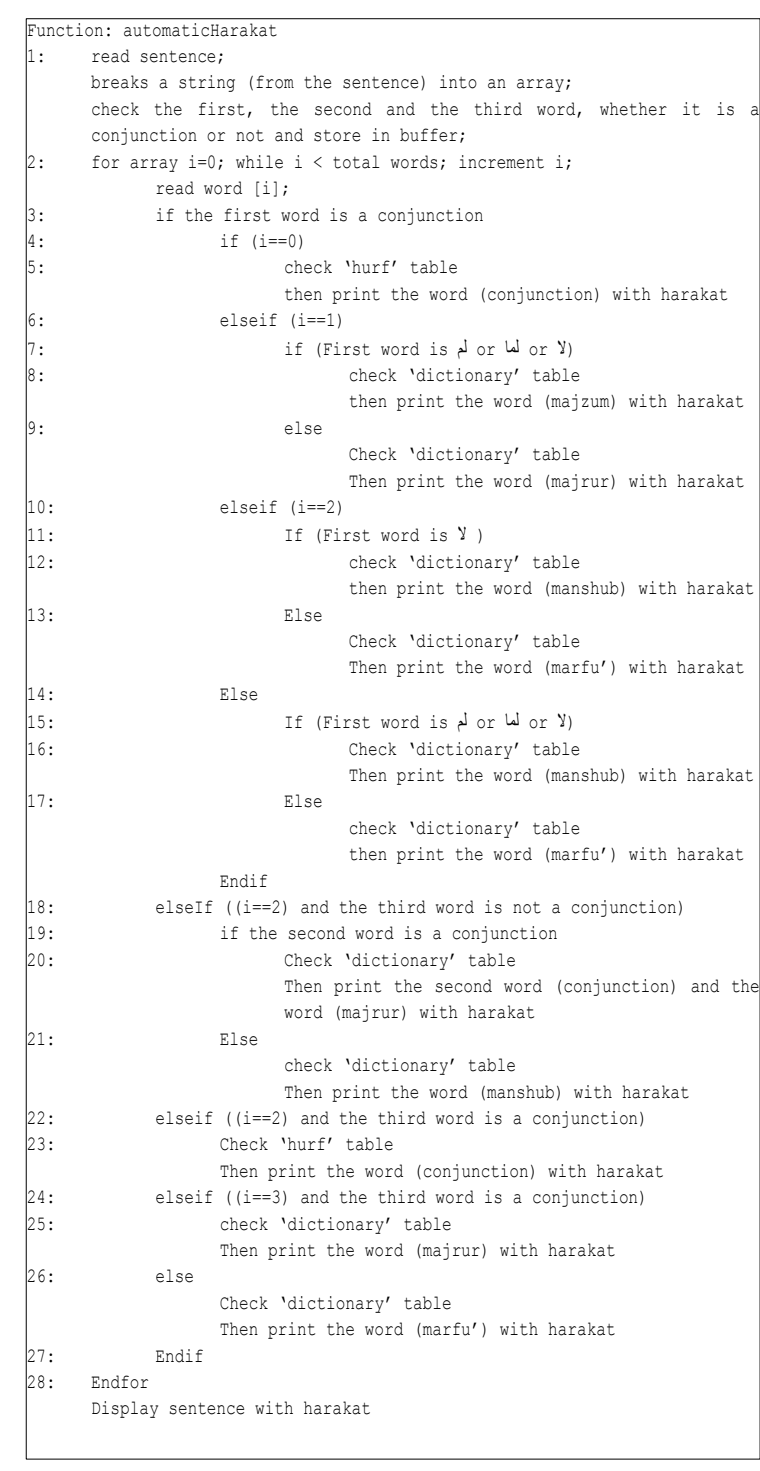

Figure 3. The Algorithm of Giving Automatic Harakat. 


\section{The Algorithm Testing}

The algorithm testing has been done by utilizing Cyclomatic Complexity White Box Testing. There are three steps in this testing method, as follows:

1) Create the Flowgraph

Figure 4 shows the flowgraph of the algorithm. The number of the node in the flowgraph refer to the number in the left from algorithm in Figure 3 (number 1 untill 28).

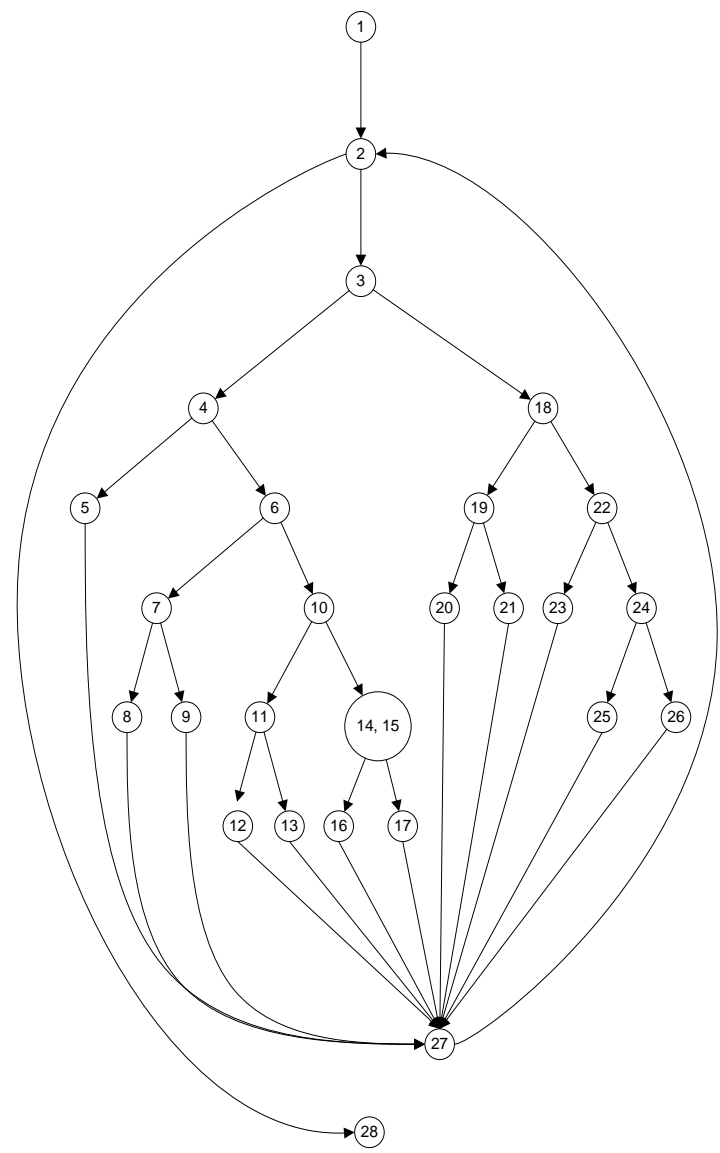

Figure 4. Flowgraph

2) Calculate the Independent Path

Total of Region $=13$

$\mathrm{V}(\mathrm{G})=$ Edge - Node +2

$\mathrm{V}(\mathrm{G})=38-27+2=13$

$\mathrm{V}(\mathrm{G})=\mathrm{P}+1$

$\mathrm{V}(\mathrm{G})=12+1=13$

So, there will be 13 independent paths that need to be examined which is shown in Table 3 .
Table 3: Independent Path

\begin{tabular}{cl}
\hline Path No. & Independent Path \\
\hline 1 & $1-2-3-4-5-27-2-28$ \\
2 & $1-2-3-4-6-7-8-27-2-28$ \\
3 & $1-2-3-4-6-7-9-27-2-28$ \\
4 & $1-2-3-4-6-10-11-12-27-2-28$ \\
5 & $1-2-3-4-6-10-11-13-27-2-28$ \\
6 & $1-2-3-4-6-10-14,15-16-27-2-28$ \\
7 & $1-2-3-4-6-10-14,15-17-27-2-28$ \\
8 & $1-2-3-18-19-20-27-2-28$ \\
9 & $1-2-3-18-19-21-27-2-28$ \\
10 & $1-2-3-18-22-23-27-2-28$ \\
11 & $1-2-3-18-22-24-25-27-2-28$ \\
12 & $1-2-3-18-22-24-26-27-2-28$ \\
13 & $1-2-28$ \\
\hline
\end{tabular}

3) Create Test Case

The independent path obtained in Table 3 will be examined using a test case scenario. Based on the interview results with experts conducted earlier and have been explained also in Table 1, there are six examples of sentences that will be used for the test case scenario. See Table 4.

Table 4. Sample Sentences

\begin{tabular}{|c|c|c|}
\hline No & Input Sentence & Expected Result \\
\hline 1 & في الفصل تلميذ جميل & فِى الفَصْنلِ تِلْمِيْنِ جَمِيْلْ \\
\hline 2 & لم يأكل محمَد الرَّز & 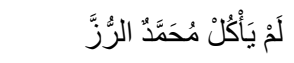 \\
\hline 3 & لا تنس المعروف & لَا تَنْسَ المَعْرُفَ \\
\hline 4 & كتب أحمد الدرس & كَََبَ أَحْمَدُ الدَرْنَ \\
\hline 5 & القلم علي الدكتب & القَلَمُ عَلَي التَكَتَبَبِ \\
\hline 6 & يذهب أحمد إلي الددرسة & يَذْهَبُ أَحْمَدُ إلَلَى المَدْرَسَةِة \\
\hline
\end{tabular}


Test case of the algorithm can be seen in Table 5 .

Table 5: Test Case of the Algorithm

\begin{tabular}{|c|c|c|c|c|c|}
\hline $\begin{array}{c}\text { Example } \\
\text { No. }\end{array}$ & Input & $\begin{array}{l}\text { Path } \\
\text { No. }\end{array}$ & Independent Path & $\begin{array}{c}\text { Expected } \\
\text { Result (Output) }\end{array}$ & Actual Result \\
\hline \multirow[t]{6}{*}{1} & في الفصل تلميذ جميل & & & $\begin{array}{l}\text { System will } \\
\text { display: }\end{array}$ & As expected \\
\hline & في & 1 & $\begin{array}{l}\text { 3: if the first word is a } \\
\text { conjunction } \\
4: \text { if ( } \mathrm{i}==0 \text { ) } \\
\text { 5: check 'hurf' table } \\
\text { then print the word } \\
\text { (conjunction) with harakat }\end{array}$ & $\begin{array}{l}\text { System will read } \\
\text { the word from } \\
\text { database: }\end{array}$ & As expected \\
\hline & الفصل & 3 & 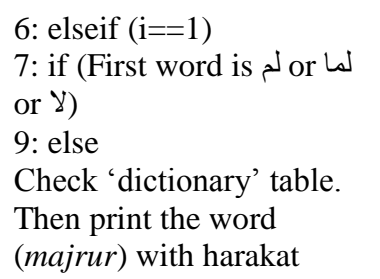 & $\begin{array}{l}\text { System will read } \\
\text { the word from } \\
\text { database: }\end{array}$ & As expected \\
\hline & تلميذ & 5 & $\begin{array}{l}\text { 10: elseif (i==2) } \\
\text { 11: if (First word is } \searrow \text { ) } \\
\text { 13: Else } \\
\text { Check 'dictionary' table } \\
\text { Then print the word } \\
\text { (marfu') with harakat }\end{array}$ & $\begin{array}{l}\text { System will read } \\
\text { the word from } \\
\text { database: }\end{array}$ & As expected \\
\hline & جميل & 7 & $\begin{array}{l}\text { 14,15: Else } \\
\text { If (First word is } ل \text { or }{ }^{\text {or }} \\
\text { ل) } \\
\text { 17: Else } \\
\text { check 'dictionary' table } \\
\text { then print the word } \\
\text { (marfu') with harakat }\end{array}$ & $\begin{array}{l}\text { System will read } \\
\text { the word from } \\
\text { database: }\end{array}$ & As expected \\
\hline & $\begin{array}{r}\text { If (no more words } \\
\text { need to be checked) }\end{array}$ & 13 & $\begin{array}{l}\text { 28: endfor } \\
\text { display sentence with } \\
\text { harakat }\end{array}$ & $\begin{array}{l}\text { Looping stop, } \\
\text { then display in } \\
\text { the system all of } \\
\text { the words with } \\
\text { harokah into a } \\
\text { sentence }\end{array}$ & As expected \\
\hline \multirow[t]{3}{*}{2} & لم يأكل محمَد الرَّز & & & $\begin{array}{l}\text { System will } \\
\text { display: }\end{array}$ & As expected \\
\hline & & & & لَمْ بَأْكُكْن مُحَمَّدُ الرُرَّْ & \\
\hline & لم & 1 & $\begin{array}{l}\text { 3: if the first word is a } \\
\text { conjunction } \\
4: \text { if ( } \mathrm{i}==0 \text { ) } \\
5: \text { check 'hurf' table } \\
\text { then print the word } \\
\text { (conjunction) with harakat }\end{array}$ & $\begin{array}{l}\text { System will read } \\
\text { the word from } \\
\text { database: }\end{array}$ & As expected \\
\hline
\end{tabular}


Table 5: Test Case of the Algorithm (contd.)

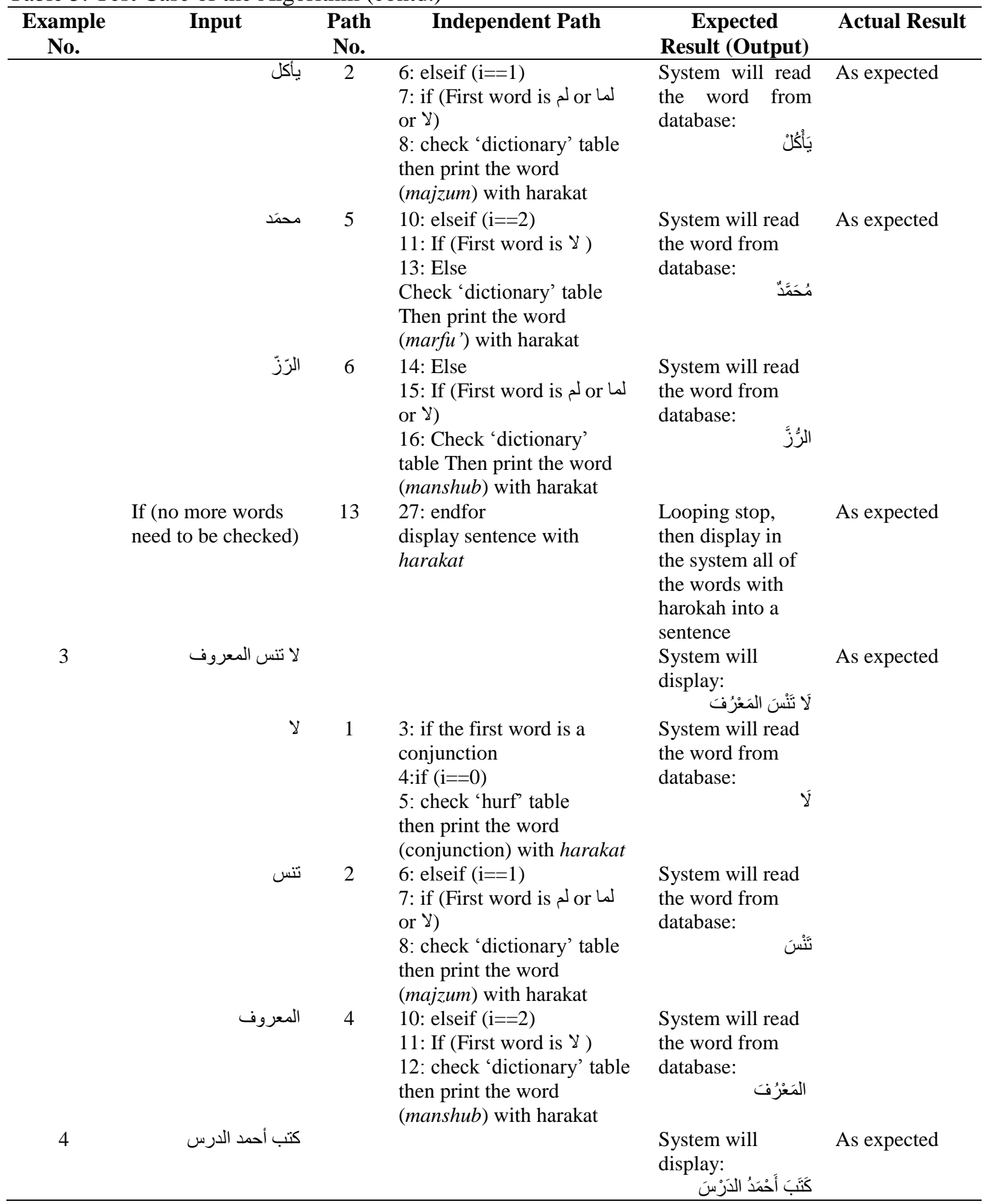


Table 5: Test Case of the Algorithm (contd.)

\begin{tabular}{|c|c|c|c|c|c|}
\hline $\begin{array}{c}\text { Example } \\
\text { No. }\end{array}$ & Input & $\begin{array}{l}\text { Path } \\
\text { No. }\end{array}$ & Independent Path & $\begin{array}{c}\text { Expected } \\
\text { Result (Output) }\end{array}$ & Actual Result \\
\hline & كتب & 12 & $\begin{array}{l}\text { 3: if the first word is a } \\
\text { conjunction } \\
\text { 18: elseIf }((\mathrm{i}==2) \text { and the } \\
\text { third word is not a } \\
\text { conjunction) } \\
\text { 22: elseif }((\mathrm{i}==2) \text { and the } \\
\text { third word is a conjunction) } \\
\text { 24: elseif ( }(\mathrm{i}==3) \text { and the } \\
\text { third word is a conjunction) } \\
\text { 26: else } \\
\text { Check 'dictionary' table } \\
\text { Then print the word } \\
\text { (marfu') with harakat }\end{array}$ & $\begin{array}{l}\text { System will read } \\
\text { the word from } \\
\text { database: }\end{array}$ & As expected \\
\hline & أحمد & 12 & $\begin{array}{l}\text { 3: if the first word is a } \\
\text { conjunction } \\
\text { 18: elseIf }((\mathrm{i}==2) \text { and the } \\
\text { third word is not a } \\
\text { conjunction) } \\
\text { 22: elseif }((\mathrm{i}==2) \text { and the } \\
\text { third word is a conjunction }) \\
\text { 24: elseif }((\mathrm{i}==3) \text { and the } \\
\text { third word is a conjunction }) \\
\text { 26: else } \\
\text { Check 'dictionary' table } \\
\text { Then print the word } \\
\text { (marfu') with harakat }\end{array}$ & $\begin{array}{l}\text { System will read } \\
\text { the word from } \\
\text { database: }\end{array}$ & As expected \\
\hline & 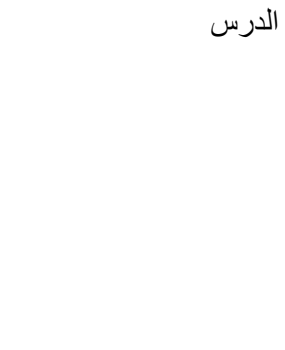 & 9 & $\begin{array}{l}\text { 18: elseIf }((\mathrm{i}==2) \text { and the } \\
\text { third word is not a } \\
\text { conjunction) } \\
\text { 19: if the second word is a } \\
\text { conjunction } \\
21: \text { Else } \\
\text { check 'dictionary' table } \\
\text { Then print the word } \\
\text { (manshub) with harakat }\end{array}$ & $\begin{array}{l}\text { System will read } \\
\text { the word from } \\
\text { database: }\end{array}$ & As expected \\
\hline & $\begin{array}{l}\text { If (no more words } \\
\text { need to be checked) }\end{array}$ & 13 & $\begin{array}{l}\text { 27: endfor } \\
\text { display sentence with } \\
\text { harakat }\end{array}$ & $\begin{array}{l}\text { Looping stop, } \\
\text { then display in } \\
\text { the system all of } \\
\text { the words with } \\
\text { harokah into a } \\
\text { sentence }\end{array}$ & As expected \\
\hline \multirow[t]{2}{*}{5} & القلم علي المكتب & & & 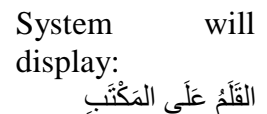 & As expected \\
\hline & 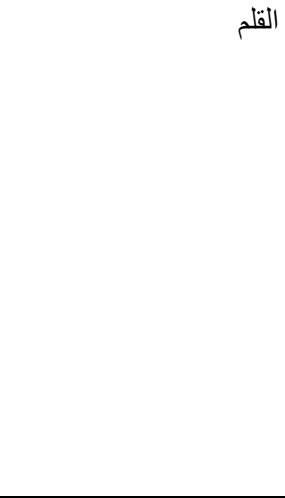 & 12 & $\begin{array}{l}\text { 3: if the first word is a } \\
\text { conjunction } \\
\text { 18: elseIf }((\mathrm{i}==2) \text { and the } \\
\text { third word is not a } \\
\text { conjunction }) \\
\text { 22: elseif }((\mathrm{i}==2) \text { and the } \\
\text { third word is a conjunction }) \\
\text { 24: elseif }((\mathrm{i}==3) \text { and the } \\
\text { third word is a conjunction }) \\
\text { 26: else } \\
\text { Check 'dictionary' table } \\
\text { Then print the word } \\
\text { (marfu') with harakat }\end{array}$ & $\begin{array}{l}\text { System will read } \\
\text { the word from } \\
\text { database: }\end{array}$ & As expected \\
\hline
\end{tabular}


Table 5: Test Case of the Algorithm (contd.)

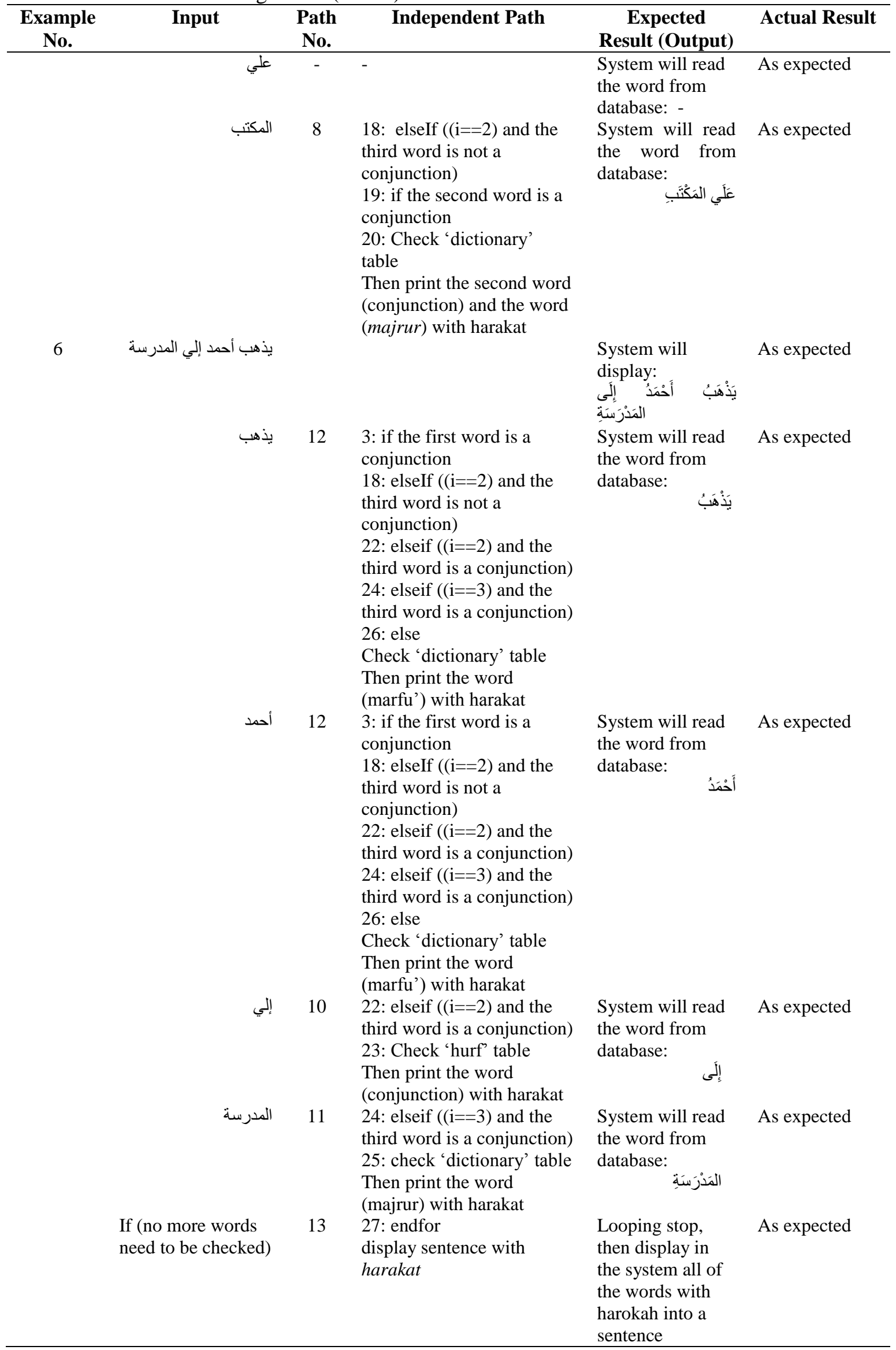


Furthermore, 24 sentences have been added to be examined for more detailed analysis.

Table 6: More Samples Examination

\begin{tabular}{|c|c|c|c|}
\hline $\begin{array}{l}\text { Condition } \\
\text { Number }\end{array}$ & $\begin{array}{l}\text { Input } \\
\text { Sentence }\end{array}$ & $\begin{array}{l}\text { Expected } \\
\text { Result }\end{array}$ & Actual Result \\
\hline \multirow[t]{5}{*}{1} & في الفصل تلميذ & 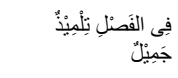 & 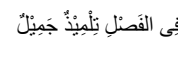 \\
\hline & فينامي البستان الكلب & 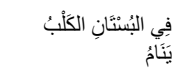 & 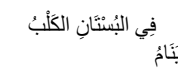 \\
\hline & فذّب النّار الحديد & 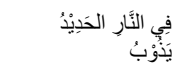 & 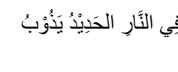 \\
\hline & يتساقط الأرض التّمر & 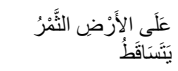 & 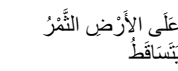 \\
\hline & العصى الثُجرة يغرد & 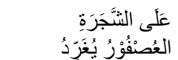 & 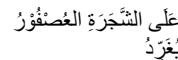 \\
\hline \multirow[t]{5}{*}{2} & لم يذهب تلميذ & لَمُ يَذْهَبْ تِلْمِيٌِْ & 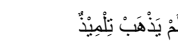 \\
\hline & لم يأكل محمَّد التزّ & 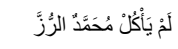 & 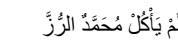 \\
\hline & لم يجلس الضيف & 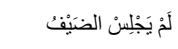 & 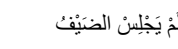 \\
\hline & للم يكتب التلميذ & 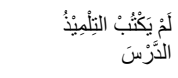 & 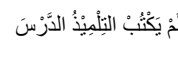 \\
\hline & لم يحضر محمّد & لَمْ يَخْضُرْ مُحَمَدْ & 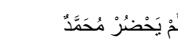 \\
\hline \multirow[t]{5}{*}{3} & لا تثرب الماء & لَا تَنَرْرَبْ الَّاءة & لا تَتَرْرَبْ المَّاءَ \\
\hline & لا تنس المعروف & 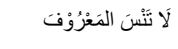 & 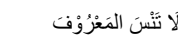 \\
\hline & لا تكتب الدّرس & لَا تَكَتُبْ الدَرَّنَ & لا تَكَتُبْ الدَّرَسنَ \\
\hline & لا تأكل الحبز & 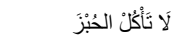 & 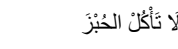 \\
\hline & لا تضرب الكلب & لَا تَضْرِبْ الكَلَبْ & لا تَضْرِبْ الكَّبَ \\
\hline \multirow[t]{5}{*}{4} & كتب أحمد الدرس & كَتَبَ أَحْمَدُ الدَرَسنَ & كَتَبْ أَحْمَدُ الدَرَسَ \\
\hline & القطّاعب إسماعيل & 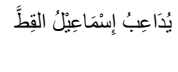 & 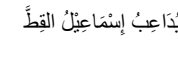 \\
\hline & الَقمصح الفَّاح & 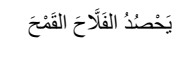 & 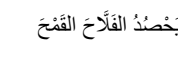 \\
\hline & يحبَ الولد البرتقال & 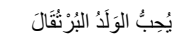 & 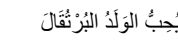 \\
\hline & يحترق الحطب & يَحَتَرِقُ الحَطَبْ & 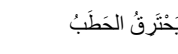 \\
\hline \multirow[t]{5}{*}{5} & المُّائرة فوق & 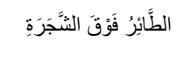 & 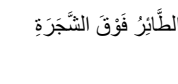 \\
\hline & القصصفور في & 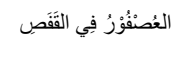 & لعُصنُفُورُ فِي العَفَصِ \\
\hline & الدداد في الذَّاة & المدَدَادُفِي الدُوَاةِ & لَِِدَادَ فِي الدََّاةِ \\
\hline & القمر في الستماء & القَمَرُ فِي السََّّاء & القَمَرُ فِي السَّمَاءٍ \\
\hline & الطَّلل على السَر يَر & الطِّفْلُ عَلَى السَّرَيْرِ & 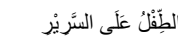 \\
\hline
\end{tabular}

Table 6: More Samples Examination (contd.)

\begin{tabular}{|c|c|c|c|}
\hline $\begin{array}{c}\text { Condition } \\
\text { Number }\end{array}$ & $\begin{array}{c}\text { Input } \\
\text { Sentence }\end{array}$ & $\begin{array}{l}\text { Expected } \\
\text { Result }\end{array}$ & Actual Result \\
\hline \multirow[t]{5}{*}{6} & 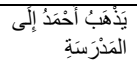 & 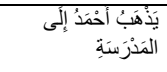 & 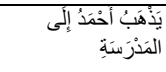 \\
\hline & الدذربة أحمد إلى & 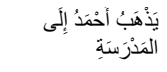 & 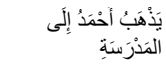 \\
\hline & من الأستاذ النّصيحة & 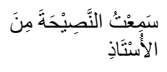 & 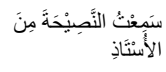 \\
\hline & الحجرة النّور في & 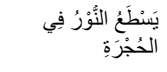 & 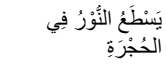 \\
\hline & تجلى ألماء السّفينة & 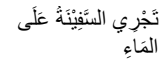 & 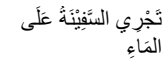 \\
\hline
\end{tabular}

\section{System Implementation}

Figure 5 shows the interface of user where user can input a sentence without harakat. After clicking the 'Put Harakat' button, user can see the sentence with harakat.

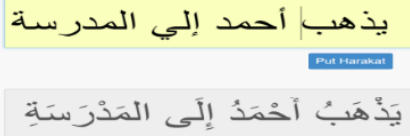

Figure 5. System Implementation

\section{RESULT AND DISCUSSION}

The results of the test case from Table 5 and Table 6 match the expected output (as written 'as expected' in Table 5). Furthermore, twentyfour examples (Table 6) have been examined and also match the expected output.

Initially this research refers to the research conducted by Sembok [13] \& Ata and Hadni et al [14], where Arabic Stemming and Arabic Text Mining give considerations how to provide harakat to Arabic sentence by searching the basic word of each words to determine the end of the harakat of the word based on Arabic grammar. However, as the study progresses, the process of searching the basic word is perceived to make the algorithm works too long and ineffective. Hence, the author insists on applying the Nahwu-Sharf science not to the code (by searching for the base word of each words, then determines the appropriate harakat at the end of the letter of the word), but apply the Arabic Grammar (Nahwu-Sharf science) to the database. Where is in the database, words are separated according to the rules, which are: marfu', 
manshub, majzum, majrur and the word without harakat. And this method result accuracy $100 \%$ in accordance with the rules of Nahwu-Sharf science.

Besides, the value of Cyclomatic Complexity obtained is thirteen which is more than 10. Kanjilal [15] stated that if the complexity cyclomatic of the algorithm is less than or equal to 10 , the algorithm is assumed to be well-structured, highly testable and maintainable. Kanjilal [15] also suggested to use Polymorphism which is able to replace the conditional constructs of code/algorithm to reduce the cyclomatic complexity of the algorithm.

\section{REFERENCES}

[1] A. Sirajudeen and A. Adebisi, "Teaching Arabic as a second language in Nigeria," Procedia-Soc. Behav. Sci., vol. 66, pp. 126-135, 2012.

[2] Chick, A.R., "Al-Alfaz al-arabiyyah almuqtaradhah fi al-lughah almalayuwiyyah: ‘ardhunwatahlil," 2011. [Online].

Available:http://portal.arabtime.com/article _preview.cfm?Action=Article \&Preview $=\mathrm{V}$ iewOnly\&ArticleID=21827. [Accessed: 10-Nov-2017].

[3] R. L. Oxford, Language Learning Styles and Strategies. Mouton de Gruyter, 2003.

[4] Greene, R., "Why learning Arabic is so hard.," 2017. [Online]. Available: http://www.slate.com/articles/arts/cultureb ox/2005/06/im_trying_to_learn_arabic.htm 1. [Accessed: 10-Nov-2017].

[5] M. Abdurrahman, "Rule of Nahwiyah Variations in Arabiyah Bayna Yadaik Book and its Contribution on Arabiyah Asasiyah Subject," J. Educ. Learn. EduLearn, vol. 9, no. 3, pp. 256-266, 2015.

[6] Shanhaji, A., Al Imam Matn al jurmiyah. Jakarta: Al Idrus, 2000.

[7] "Madinah Arabic Learn Arabic For Free," 2017.[Online].Available:http://www.madin aharabic.com/articles/the-story-ofirab.html. [Accessed: 10-Nov-2017].

[8] "Basic Arabic Grammar (Nahu)," Ummah.com - Muslim Forum,

\section{CONCLUSION}

Since the entered word is according to the conditions of the algorithm (refer to Table 1), the results of the test case match the expected output. Thus, it can be concluded that the generated algorithm has been proven in accordance with the rules of Nahwu-Sharf science through Cyclomatic Complexity testing. This algorithm is expected to be implemented on a development system that can assist students and institutions who learn Arabic to automatically generate harakat based on user input.

2017.[Online].Available:https://www.umm ah.com/forum/forum/library/learn-arabicand-other-languages/218451-basic-arabicgrammar-nahu. [Accessed: 10-Oct-2017].

[9] Ö. Ergül, Guide to programming and algorithms using R. Springer, 2013.

[10]A. A. Puntambekar, Analysis of algorithm and design. Technical Publications, 2009.

[11]R. S. Pressman, Software Engineering. Palgrave Macmillan, 2001.

[12] "Cyclomatic Complexity," 2017. [Online]. Available:http://www.math.unipd.it/ tullio /IS-1/2004/Approfondimenti/cyclomatic. htm. [Accessed: 10-Oct-2017].

[13]T. M. T. Sembok and B. A. Ata, "Arabic word stemming algorithms and retrieval effectiveness," in Proceedings of the World Congress on Engineering, 2013, vol. 3, pp. 3-5.

[14]M. Hadni, S. A. Ouatik, and A. Lachkar, "Effective Arabic stemmer based hybrid approach for Arabic text categorization," Int. J. Data Min. Knowl. Manag. Process, vol. 3, no. 4, p. 1, 2013.

[15]Kanjilal, J., "How to analyze the cyclomatic complexity in your code | InfoWorld,"

2017.[Online].Available:https://www.info world.com/article/3097404/applicationdevelopment/how-to-analyze-thecyclomatic-complexity-in-your-code.html. [Accessed: 10-Oct-2017]. 